\title{
Experience of business owner Coffee shops and size of enterprises on sustainable perspectives
}

\author{
Mokhamad Syaefudin Andrianto ${ }^{1}$, Stevia Septiani ${ }^{2}$, Mukhamad Najib $^{3}$, Hardiana Widyastuti ${ }^{4}$ \\ \{syaefudin1@apps.ipb.ac.id ${ }^{1}$, steviaseptiani@apps.ipb.ac.id ${ }^{2}$, najib@apps.ipb.ac.id ${ }^{3}$, \\ hardiana.widyastuti@apps.ipb.ac.id $\left.{ }^{4}\right\}$ \\ IPB University ${ }^{1234}$
}

\begin{abstract}
Coffee shops in Bogor city have been growing rapidly and raised questions about sustainability. This article aims to analyze different perspectives on sustainability with variables of product innovation, market orientation, and marketing performance expectation based on business owner experience. As many 110 business owners had interviewed. Indicators of Expectation on profit, sale in the next year and customer relation have significantly different among business experience groups. Indicators of perception on plastic usability, environment consideration in developing new products, trial error, market identification and customer reference.
\end{abstract}

Keyword : Non parametric test, SME's, Survival strategy

\section{Introduction}

Industries or business has been evolving and adapting to survive. Different Business life cycles and size of enterprises might have different strategy and sustainability perspectives. Product life cycle has five distinct stages and business strategies . The stages are product development, introduction, growth, mature and decline [1] . Company which is at a certain stage of development should build and adapt the business models in order to maintain the ability to create value for stakeholders. Characteristics of business model at the early stage of development is different than at mature stage [2]. Most of the early stage of industries or business is characterized by experimentation and a high rate of innovation. In mature stage, firms rarely introduce new products and tend to produce standard goods or services [3]. Based on time operational experience Coffee shops can be assumed into introduction, growth and mature.

The size of a company can be measured by the number of employees or capital. According to Indonesian government law No 20/2008 micro is defined by an enterprise that has a maximum asset 50 million IDR and maximum revenue 300 million IDR/year and small is enterprises that has asset between 50 million IDR and half billion IDR with revenue range from 300 million to 2.5 billion IDR/year. BPS defines the size of a company by the number of employees, micro is an enterprise with number employees less than 5 and small 
is an enterprise with number employees between 5 to 20 people. Almost all new Coffee shops that have been growing in Bogor, based on the size of enterprises, can be divided into micro and small.

Sustainability is an essential issue for business. Rapid and massive growing new coffee shops in Bogor have been raising questions whether the Business will sustain or not. Do some characteristics of enterprises (size, type of ownership and gender) are different in business life cycle? and Do enterprises have different sustainability perspectives in the business life cycle? Sustainability expectation based on owners' perception can support decision makers such as investors and entrepreneurs to take action in this industry. This article has the purpose to identify the difference size of enterprises and sustainability perspectives in business life cycle.

Business life cycles based on owner experience and size of enterprises are presumed to have different perspectives on sustainability. There are some aspects related to sustainability perspectives such as innovation in product, process and marketing [4]. Product innovation affected marketing capabilities and marketing performances [5,6]. Marketing innovation and marketing orientation have significant effects on marketing performance [7,8]. Product competitor orientation has significant effects on innovation and marketing performance[9]. So the hypothesis alternatives are;

Ha1: statistically significant differences exist in the stage business of life cycle for the characteristics of enterprises (size of capital, size of employee, type of ownership and gender ownership.

Ha2: statistically significant difference exist in the stage business of life cycle for sustainability perspectives

\section{Methods}

\subsection{Data collection}

The research was conducted in Bogor which has significant growing number of coffee shops in the last ten years. A convenience sampling was applied to collect the data from 110 business owners or managers who running coffee shops. Observation, survey and in depth interviews were conducted by student surveyor teams with google form as an instrument to gather the data.

\subsection{Data analysis}

Coffee shops business life cycle was assumed the same with time of business operational/experience and divided into three groups; new business (less than 12 month), growth (12-36 months) and mature (more than 36 
months). Based on size of employee, the data divided into two groups; micro (less than 5 employee) and small (more than 5 employee). Based on revenue, the data was divided into micro (revenue less than 300 million IDR/year) and small (revenue between 300 million IDR to 2.5 Billion IDR). The data was processed by descriptive analytic, pearson chi square test and ANOVA test.

The sustainability of product innovation was represented by statements of continuous product improvement (PS1), Product development considered environment factors (PS2), Avoid plastics, aluminium and polystyrene as drink jar (PS3), and always looking for new ideas and information to innovate products (PS4). Marketing sustainability was indicated by statements market identification by trial and error (MS1), referral marketing by customer (MS2), owner contact directly by special clients (MS3), employees understand customer problems and observe competitors (MS4). Marketing performance expected was related to statements selling will increase (MP1), Customer satisfaction will increase (MP2) and profit prediction will increase (MP3).

\section{Result}

\subsection{Respondent Characteristics}

Majority coffee shops were owned by individuals (59\%) and owners dominated by men (80\%). Coffee shops promotion used social media $(90 \%)$ and all social media promotion used Instagram and others such as Facebook (14\%) and Twitter (5\%) (Table 1). Promotion is very important to create a positive image [10]. Promotion via internet especially electronic word of mouth has positive effect to increase sales [11]. 
Table 1. Characteristic of Coffee shops

\begin{tabular}{lrr}
\hline Variables & $\mathrm{N}$ & $\%$ \\
\hline Type of Ownership & 65 & 59.1 \\
Individual & 37 & 33.6 \\
Joint & 8 & 7.3 \\
Franchise & & \\
Owner Gender & 88 & 80 \\
Man & 20 & 18.2 \\
Woman & 2 & 1.8 \\
Man \& woman & & \\
Social Media Promotion & 100 & 90.9 \\
Use & 10 & 9.1 \\
No & 100 & 100 \\
Type of Social Media (possible more than one) & \\
Instagram & 14 & 14 \\
FB & 5 & 5 \\
Others & & \\
\hline
\end{tabular}

Based on experience or business operational Coffee shops were varied from 1 month to 12 years with an average 22 months. Number of employees vary from 1 until 24 with an average 6 employees and income minimum 0.4 million IDR/month and maximum 480 million IDR/month with average 43 million IDR/month (Table 2).

Table 2. Size of business and revenue

\begin{tabular}{lrrr}
\hline Variables & Min & Max & Average \\
\hline Experience (month) & 1 & 144 & 22 \\
Number of Employee & 1 & 24 & 6 \\
Income (Million IDR/months & 0.4 & 480 & 43 \\
\hline
\end{tabular}

\subsection{Comparison based on Experience with size of employee, income, ownership and gender}

There were some significant business characteristic comparisons based on experience especially for Size by employee and size by income. Majority new Coffee shops was categorized to micro and the majority of mature was categorized to small coffee shops. Pearson Chi Square had applied to test difference characteristics of size enterprises, type of ownership, and gender ownership in the stages of business life cycle (Table 3). There were differences for enterprises size both based on employee and income and no difference type ownership and gender ownership on Business life cycle stages. Mature stage was dominated by small size and newcomers were dominated by micro business. 
Table 3. Business life cycle and some characteristics

\begin{tabular}{lrrrrr}
\hline Variables & New & Growth & Mature & Pearson Chi Square test & Sig. \\
\hline Size by Employee & & & & 11.657 & $0.003^{*}$ \\
Micro & 47 & 16 & 7 & & \\
Small & 16 & 10 & 14 & & \\
Total & 63 & 26 & 21 & 7.784 & $0.02^{*}$ \\
\hline Size by Income & & & & & \\
Micro & 40 & 11 & 7 & & \\
Small & 18 & 11 & 13 & & 0.333 \\
Total & 58 & 22 & 20 & & \\
\hline Ownership & & & & & \\
Individual & 34 & 15 & 16 & & \\
Joint & 24 & 8 & 5 & & \\
Franchise & 5 & 3 & 0 & & \\
Total & 63 & 26 & 21 & & \\
\hline Gender Ownership & & & & & \\
Man & 55 & 20 & 13 & & \\
Woman & 7 & 6 & 7 & & \\
Man \& Woman & 1 & 0 & 1 & & \\
Total & 63 & 26 & 21 & & \\
\hline
\end{tabular}

\subsection{Comparison Experience and of sustainable perspective of innovation production, marketing orientation and marketing performance.}

Based on the Anova test, comparison means perceptions of product, marketing orientation and marketing performance, there were partially significant different perceptions (Table 4). Mature coffee shops tend more to avoid plastics, aluminium and polystyrene as drink jars (PS3) and have more emphatic employees (MS4). Growth coffee shops have a tendency to always look for new ideas and information to innovate products(PS4), owner more effort to contact customers (MS3) and have good perception or are more optimistic about selling (MP1) and profit compared to last year (MP3). 
Table 4. Business life cycle and perspective of product innovation, marketing innovation and marketing performance

\begin{tabular}{|c|c|c|c|c|c|c|}
\hline Variable & new & growth & mature & Total & $\mathrm{F}$ & Sig. \\
\hline PS1 & 4.51 & 4.50 & 4.10 & 4.43 & 2.64 & 0.08 \\
\hline PS2 & 3.56 & 3.50 & 3.90 & 3.61 & 1.27 & 0.28 \\
\hline PS3 & 3.00 & 3.15 & 3.76 & 3.18 & 4.05 & $0.02 *$ \\
\hline PS4 & 4.44 & 4.68 & 4.00 & 4.41 & 4.05 & $0.02 *$ \\
\hline MS1 & 3.95 & 4.32 & 3.76 & 4.00 & 2.29 & 0.11 \\
\hline MS2 & 4.10 & 4.08 & 3.81 & 4.04 & 0.93 & 0.40 \\
\hline MS3 & 3.89 & 4.40 & 3.71 & 3.97 & 3.64 & $0.03 *$ \\
\hline MS4 & 4.16 & 4.38 & 4.57 & 4.29 & 3.08 & $0.05 *$ \\
\hline MS5 & 3.73 & 4.12 & 3.86 & 3.85 & 1.56 & 0.21 \\
\hline MP1 & 3.81 & 4.35 & 4.24 & 4.02 & 4.20 & $0.02 *$ \\
\hline MP2 & 4.03 & 4.31 & 4.19 & 4.13 & 1.11 & 0.33 \\
\hline MP3 & 3.79 & 4.38 & 4.19 & 4.01 & 4.55 & $0.01 *$ \\
\hline Code & \multicolumn{6}{|c|}{ Variables } \\
\hline PS1 & \multicolumn{6}{|c|}{ Continuous product improvement } \\
\hline PS2 & \multicolumn{6}{|c|}{ Product development consider environment factors } \\
\hline PS3 & \multicolumn{6}{|c|}{ Avoid plastics, aluminium an polystyrene (as drink jars) } \\
\hline PS4 & \multicolumn{6}{|c|}{ Always looking for new idea and information to innovate product } \\
\hline MS1 & \multicolumn{6}{|c|}{ Market identification by trial and error } \\
\hline MS2 & \multicolumn{6}{|c|}{ Referral marketing by customer } \\
\hline MS3 & \multicolumn{6}{|c|}{ Owner trial contact directly with customer } \\
\hline MS4 & \multicolumn{6}{|c|}{ Employee understand the customer problems } \\
\hline MS5 & \multicolumn{6}{|c|}{ Always observe competitor } \\
\hline MP1 & \multicolumn{6}{|c|}{ Selling perception increase than a year ago } \\
\hline MP2 & \multicolumn{6}{|c|}{ Customer satisfaction increase than a year ago } \\
\hline MP3 & \multicolumn{6}{|c|}{ Profit prediction increase than a year ago } \\
\hline
\end{tabular}

\section{Conclusion}

New coffee shops in Bogor were dominated by micro enterprises with employees less than 5 and income less than 300 million IDR/year with individual ownership. Instagram has become the main social media tool to promote coffee shops.

Based on life cycle analysis, small coffee shops looked more survival compared to micro coffee shops. However there were no significant differences in type of ownership and gender ownership in the business life cycle stages. Based perception, mature coffee shops have differences on looking for new ideas and effort to contact customers and also perception of optimistic selling and profit. This research proves life cycle processes based on time of experience have different perceptions on material to use, innovate product, marketing relationship and are optimistic of marketing performance. 


\section{Reference}

[1] Armstrong G, Kotler P, Opresnik MO. Marketing An Introduction. Thirteenth. Pearson Education Limited; 2017.

[2] Jabłó A, Jabłó M, Rosen MA. Research on Business Models in their Life Cycle 2016;8:430. https://doi.org/10.3390/su8050430.

[3] Klimenko MM. Competition, matching, and geographical clustering at early stages of the industry life cycle. J Econ Bus 2004;56:177-95. https://doi.org/10.1016/j.jeconbus.2003.12.001.

[4] Arani N, Ramadhania, Barkah. The Journey of Innovation : A Challenge on SME' s in Achieving Sustainable Competitive Advantage. J Res Business, Econ Manag 2020;14.

[5] Farida N. Determinants of Marketing Performance: Innovation, Market Capabilities and Marketing Performance. J Din Manaj 2016;7:59. https://doi.org/10.15294/jdm.v7i1.5759.

[6] Sholekhuddin M, Marlena N. Increasing Marketing Performance Of Milkfish Processing Micro Small And Medium Enterprise (MSMES) In East Java: Both Product Innovation And Supply Chain Still Can Do? 2018;16:58-66.

[7] Handoyo AS. The effect of marketing innovation, market orientation, and social capital on competitive advantage and marketing performance: A study in MSMEs of embroidery Central Java Province. J Econ Bus Account Ventur 2015;18:351. https://doi.org/10.14414/jebav.v18i3.506.

[8] Shinta Dewi. Pengaruh orientation market dan product innovation terhadap performance marketing pada perusahaan pt. novapharin gresik. J Ilmu Ekon Dan Manaj 2019;6:01-15. https://doi.org/.1037//0033-2909.I26.1.78.

[9] Arief HSHM. Building Marketing Performance Through Competitor Orientation (Empirical Study on Baitul Maal wat Tamwil at Ex-Residency of Semarang). J Sains Pemasar Indones 2018;XVII:1401-151.

[10] Nurul Fildzah A, Dwi Mayangsari I. Analisis Strategi Promosi pada UMKM Social Enterprise (Studi Kasus Pascorner Cafe and Gallery). J Komun 2018;12:101-12. https://doi.org/10.20885/komunikasi.vol12.iss2.art1.

[11] Sugianto IW, Pratomo LA. Pengaruh Self-Relevant Value dan Cafe-Relevant Value Terhadap Electronic Word-Of-Mouth. Media Ris Bisnis Manaj 2019;18:19. https://doi.org/10.25105/mrbm.v18i1.4990. 